\title{
If Other, Specify
}

National Cancer Institute

\section{Source}

National Cancer Institute. If Other, Specify. NCI Thesaurus. Code C157101.

A directive to specify when the listed responses are not sufficient. 